\title{
The interaction of service quality, customer value, customer satisfaction on customer's behaviour intention using cellular/mobile service in Ho Chi Minh City
}

\author{
Do Thi Thanh Tram ${ }^{1 *}$, Nguyen Khanh Duy ${ }^{2}$ \\ ${ }^{1}$ Shin Heung Dong Nai company, Vietnam \\ ${ }^{2}$ University of Economics Ho Chi Minh City, Vietnam \\ *Corresponding author: thanhtram.sim@gmail.com
}

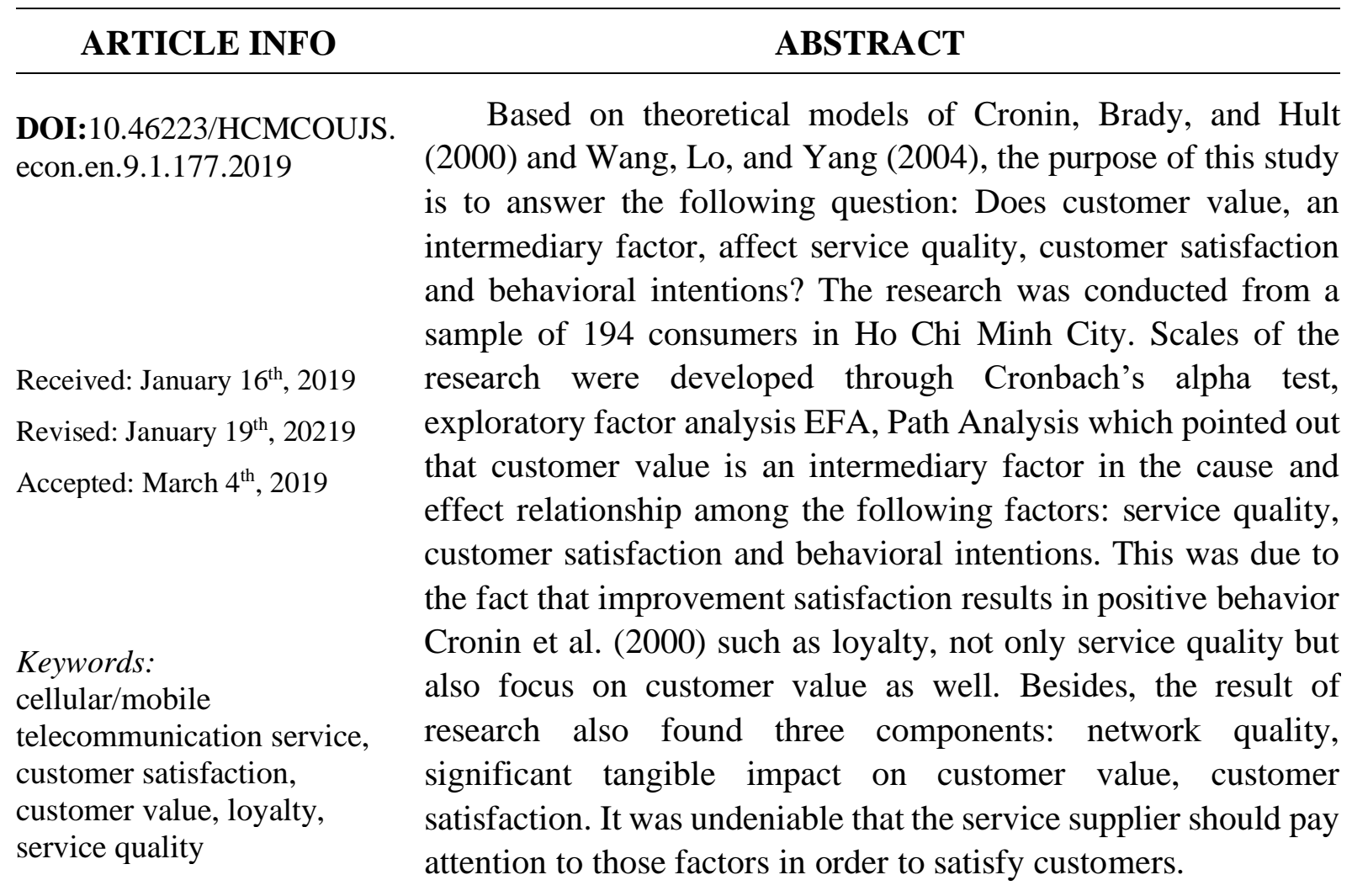

\section{Introduction}

In the era of information and technological advances, the need to communicate increasingly becomes a fundamental need are two main reasons for mobile telecommunications services to become commonplace and top priority of human life. The fast-growing market, the number of suppliers involved in the market increase, the more battle to gain market share between "old people", "new people" in the mobile telecommunication services Vietnam more and more fierce, mass and hard.

Competitive strategies are also diversified such as pricing strategies, advertising, promotion, discounts, customer care, quality of basic services as well as added-value services. The above mentioned are not aimed at achieving the three most important competitive advantages of the business: quality of customer service (service quality), value of services 
provided to customers added value services and customer satisfaction (Parasuraman, Zeithaml, \& Berry, 1998; Zeithaml, Berry, \& Parasuraman, 1996).

Customer behavior research is one of the key issues of marketing research as well as the marketing department of companies. Previous studies in mobile communications in Vietnam were concerned with measuring service quality or the impact of service quality on customer satisfaction resulting in loyalty; Nevertheless, customer value (customer service value), customer behavior is rarely mentioned in the studies. Meanwhile, Cronin et al. (2000) in their research on the relationship among four factors: service quality, service value, satisfaction, and customer behavior in the 6 service sectors in the United States. Indirect service quality to customer satisfaction through customer value, and customer value have a positive and significant impact on customer behavior (behavior intention). Wang et al. (2004) using the research model of Cronin et al. (2000) in the Chinese mobile telecommunications industry has shown that service quality does not directly affect customer behavior.

\section{Literature review and methodology}

\subsection{Service quality}

It can be deniable that measuring service quality for specific industries is also of interest to many authors in Vietnam (e.g., Dao, 2017; Phan, 2015;). Dao (2017) used the SEVQUAL model to evaluate the quality of specialized supermarket services in Hanoi with the statistical techniques described in the comparison between expectations and customers' perception. This approach is useful in measuring service quality and towards practical solutions, but has failed to validate the rules of the effect of service quality with other related concepts in theory. Phan (2015) presents a number of studies related to the relationship between service quality and customer satisfaction or (or) loyalty in some areas (retail service in super general market in Hanoi: with regression techniques, ATM card services of Military Joint Stock Commercial Bank in Hanoi, FPT Internet services in Hanoi: multiple regression techniques, hotel services in some hotels 3-star hotel in Danang: multiple regression techniques. Some researches in Phan (2015) only survey the customer of a company, so it may be difficult to make sense in the generalization to the whole. Because of the insufficient variation of the independent variables, the two regression equations separately apply to the effect of the quality components of the translation. Satisfaction and loyalty can lead to biases in estimation because satisfaction and loyalty are not independent of each other but they have a causal relationship.

Review globally with and authors service quality is a catchy concept and has many different definitions in this research the authors try to cover some key definitions i.e., according to Edvardsson, Thomsson and Ovretveit (1994), service quality is the fulfillment of customer expectations for service and satisfying their needs. In addition, service quality is also viewed as the distance between customer expectations and perceptions when used through service (Parasuraman et al., 1985, 1988). 
Regarding, the approach of Parasuraman et al. $(1985,1988)$, the initial model of service quality measurement consisted of multiple components: Reliability, Responsiveness, Competence, Courtesy, Communication, Credibility, Security, Understanding the customer. Then, in 1988, Parasuraman et al. (1988) modified and modeled the SERVQUAL model to measure service perceptions through five components, including:

1. Reliability: demonstrates the ability to deliver the right service on time.

2. Responsiveness: performs the willingness of service personnel to provide timely service to customers.

3. Service capacity (assurance): shows the professional level and the way to serve courtesy, hospitality with customers.

4. Empathy: express the care and attention to each individual customer.

5. Tangible means (tangibles): represents through the appearance, dress of service personnel, equipment to provide services.

The five-component SERVQUAL model was also applied by Cronin and Taylor (1992). However, each service sector in different markets may have specific characteristics to adjust; For example, with the service quality in the mobile telecommunications sector, in addition to these five basic components, network quality (Wang et al., 2004); In particular, the quality of the network consists of five aspects: (1) the quality of the network call is in good use, rarely dropped, interference; (2) Mobile networks provide more added value services at reasonable and competitive prices; (3) Mobile networks are using wide coverage, easy to communicate at all times; (4) make successful calls during peak hours; (5) Can connect and make calls from the first call. This paper uses the service quality measurement model of Cronin and Taylor (1992), and Cronin et al. (2000), Wang et al. (2004) and adapts it for the market for mobile telecommunication services in Ho Chi Minh City.

\subsection{Customer satisfaction}

Satisfaction is the process of customer feedback about the product or service that the product or service meets their needs and expectations (Zeithaml \& Bitner, 2000). The gap between needs and expectations is the level of satisfaction. Satisfaction is the level of a person's sense of place that results from comparing the results obtained from the product (or output) with his or her expectations (Kotler, 2001). In addition, according to Kotler, Amstrong, Saunders, and Wong (1997), customer satisfaction is their sense of either satisfaction or disappointment that results from the comparison between the cognitive performance of a product in a relationship with their expectations.

There are two levels of service satisfaction: service satisfaction provided by the provider, and service preferences (expressed by emotion) (Oliver \& Bearden, 1985). Studies by Cronin et al. (2000) offer customer satisfaction for service providers in two levels: having 
feelings (likes, dislikes, anger, surprise) and satisfaction. In this study, the concept of satisfaction only revolves around satisfaction (lightly level).

\subsection{Customer value}

The issue of value creation or added value has been widely discussed in specialized marketing and consumer articles, which are often seen as key parts of mission statements and organizational goals. The value of service is viewed as an important variable of customer satisfaction and behavior (McDougall \& Levesque, 2000). Zeithaml (1988) describes the concept of perceived value as the general appreciation of the customer for the usefulness of a product based on perceptions of what is received and what is lost. The author also identifies four definitions of value through qualitative research of clients in their research: (1) Value is low or high, (2) Value is what I want in a product (3) Value is the correspondence that I received at paid price, (4) Value is what I got back for what I lost. In general, the value is the trade-off between the gain (profit/benefit) and loss (loss /cost).

Cronin et al. (2000) in the study of the effects of service quality, value and customer satisfaction in the six service sectors in the United States used the (3) and (4) definitions to form the conceptual scale service value. In the integrated model study for the factors: service quality, customer value perceived from the service, customer satisfaction in the Chinese mobile telecommunications market, Wang et al. (2004) used the notion of customer value for his research model rather than service value, but based on definition (3) and (4) of Zeithaml (1988) on the concept of service value. In order to design a dimension scale and add a variable with the statement: Compared to competing vendors, the service provider I am using is the better choice. In this study, the author uses the two-variable scale of Wang et al. (2004) for the concept of customer value (similar to two variables in the original dimension scales of Zeithaml (1988), and Cronin et al. (2000). From the literature, it can be clear in the context of mobile telecommunication service that the chosen service is value for money and is worth what is given up such as time, energy and effort.

\subsection{Behavior intention}

The goal of marketing is to meet and satisfy the needs and desires of the target customers. Customer Behavior Category studies how individuals, groups, organizations choose, purchase, use goods and services, ideas to satisfy their customer's needs. With regard to learning behavior, this is not a simple task; it's art (Vu, 2002). Customer behavior is a field of study that has roots in the sciences such as psychology, sociology, psychology of sociology, humanities and economics. The American Marketing Association (AMA) defines consumer behavior as a reciprocal relationship, the impact of perception, emotion, and behavior. That also means consumer behavior includes their emotions, thoughts, and behaviors in the buying process. At the same time, it also includes the environment that affects the consumer's emotions, perceptions and behaviors, such as other people's comments, advertising, product price information, the appearance of the product, etc. 
Furthermore, another viewpoint from philosophy of psychology Engel, Blackwell, and Miniard (1995) show behavioral intentions related to attitudes. The traditional view reflects that attitude consists of three main components: (1) one's perception, understanding, and belief in one's attitude, (2), (3) a person's perception, action or behavior. Zeithaml et al. (1996) suggest that customer preference behavior is related to the ability of a service provider to: (1) say good and positive about them, (2) introduce the provider service to others, (3) become their loyal customer, in particular, continue to use the service of the company, (4) accept to pay higher than others. Thus, customer behavior in the context of the mobile telecommunication market is choosing a mobile service provider today the user chooses their present service provider again. Moreover, they are sure to recommend the using network and the user will keep close relationships with this service provider.

\section{Link the concepts:}

This research may have newer academic contributions compared to Phan (2015), Dao (2017) is in the context of the mobile information sector in HCMC (a dynamic city venture) based on customer perception with many different companies at the time of the survey in 2018 when the public's interest in the 4.0 industrial revolution was greater; At the same time, the author cares about two more research concepts in a model that are estimated simultaneously with Path Analysis: value of service, customer behavior; estimation using Path Analysis minimizes bias compared to individual regression equations when the dependent variable models are not independent of each other, and there are intermediate variables. Although there are inherent ways of measuring research concepts of Cronin et al. (2000) and Wang et al. (2004), this study has adapted to a dynamic market (HCMC) in a developing country (Vietnam) in the context of 2018. In addition, this study is not only concerned with the effect of service quality [in general] on other concepts that may have more detailed implications for the impact of each component concept (i.e., service quality to customer service value, customer satisfaction and behavior intention). This study concerns not only direct effects but also indirect effects as well as aggregate effects.

\subsection{Research model}

The research model of the paper is based on the research model of Cronin et al. (2000) and added network quality in service quality to Vietnam's mobile telecommunication services sector (Figure 1). In the research model, six hypotheses are expressed as follows: 


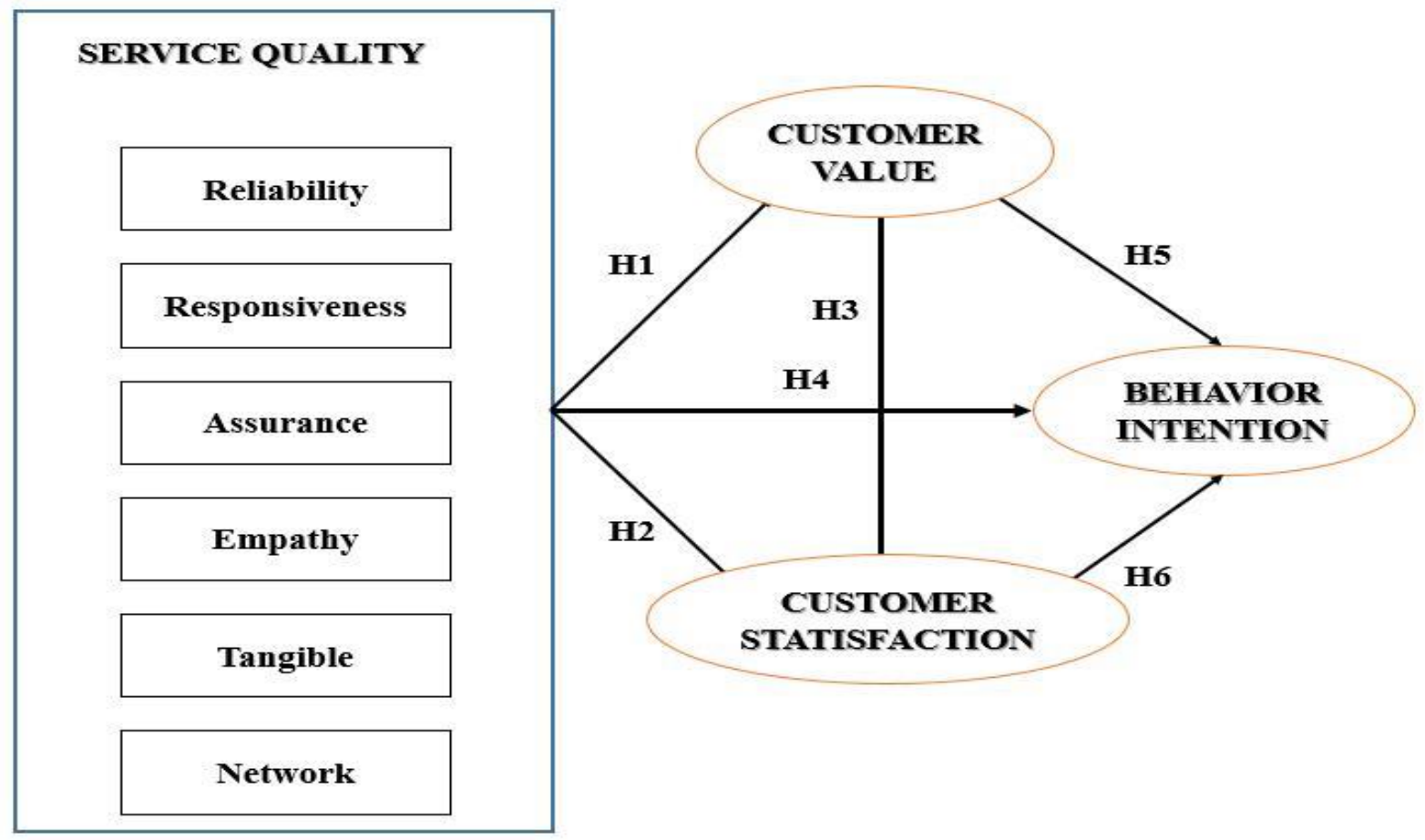

Figure 1. Research model

H1: Service quality has a positive and significant influence on customer value

H2: Service quality a positive and significant influence on customer satisfaction

H3: Customer value has a positive and significant influence on customer satisfaction

H4: Service quality has a positive and significant influence on consumers behavioural intentions (behavior intention)

H5: Customer value has a positive and significant influence on consumers' behavioural intentions (behavior intention)

H6: Customer satisfaction has a positive and significant influence on consumers' behavioural intentions (behavior intention)

The components of the quality of mobile information services in HCMC will be adjusted after the actual data collection, scale reliability analysis as well as exploratory factor analysis.

\section{Research methodology}

The study was conducted in two phases: (1) qualitative research by group discussion of 10 people aged 23-54, including students, employees, staff (with different level of educational background, occupation) who using mobile services such as Mobifone, Vinaphone, Viettel; (2) quantitative research with questionnaires emailed and face-to-face interviews with a scale used as a Likert scale of 5 points, from 1 being totally disagreed to 5 being totally agree. In particular, the scale is based on the original scale from the previous studies (see Table 1), but adjusted to suit the mobile telecommunication sector in Vietnam. 


\section{Table 1}

Dimension (scales) for research concepts

\begin{tabular}{ll}
\hline Research concepts (constructs) & Original dimension (scales) \\
\hline Service quality & Cronin and Taylor (1992) \\
(Network quality) & Wang et al. (2004) \\
Customer satisfaction & Cronin et al. (2000), Wang et al. (2004) \\
Customer value & Cronin et al. (2000), Wang et al. (2004) \\
Behavior intention & Wang et al. (2004) \\
\hline
\end{tabular}

Source: Summary by the authors.

The reliability and validity of the conceptual dimensions of the research model were assessed using the Cronbach's alpha coefficient and the exploratory factor analysis technique. Path analysis is used to test hypotheses. SPSS, AMOS software is used to support this analysis. In addition, the authors also perform descriptive analysis; The stability of the results by regression technique, correlation coefficient, but due to the limit of page numbers should not be presented in the article (readers who wish to contact the author via email for further details).

\section{Research result and discussion}

\subsection{Data Description (Characteristic of respondents)}

In order to collect data, this research conducted a convenience survey from 01 of April to 31 of May in 2018 in Ho Chi Minh, Vietnam. Convenience sampling method was used to collect data from customers (people who using mobile services Mobifone, Vinaphone, Viettel and other network providers in Ho Chi Minh City. The questionnaire was translated into Vietnamese, being printed and then distributed to customers with the help of friends and relatives. Finally, of the 300 surveys individually administered, 208 questionnaires were received at a response rate of 69.33 percent, of which 14 questionnaires were invalid due to lack of information. On further filtering, 194 responses were found to be completely filled and can be used for analysis. These 194 samples are sufficient for the purpose of this study. As a result, 194 valid questionnaires (93.27\%) were used as research data. The basic attributes of respondents are summarized: surveyed clients are male (40\%), female $(60 \%)$. Among the sample collected, male respondents make up $40 \%$ percent while female respondents are $60 \%$ percent. Most of them are the subscriber of Viettel (46.4\%), meanwhile, the subscriber of MobiFone and VinaPhone provider are 30.4 percent and 21.6 percent respectively. These three providers account for 98.5 percent of respondents. In terms of the type of contract, most of the respondents $(72.2 \%)$ are pre-paid, while the rest $(27.8 \%)$ of respondents account for post-paid services. Respondents in the age group 23-34 (74.2\%) are the majority, while respondents in the age group under 23 accounts for 15.5 percent. In other words, respondents in the age group under 35 contribute to 89.7 percent of the sample collected, while 8.2 percent of respondents are the age group 35-44. The majority of respondents are single $(65.5 \%)$, and the rest of the respondents $(34.5 \%)$ are married. The frequency distribution for monthly total income are as follows: is less than 5 million (11\%), 5-10 million (about 56\%), 10-20 million (24\%) and the 
rest is over 20 million. On occupation, the majority is private employees and small traders (35\%), students (4\%) and the remaining occupation is $(27 \%)$.

4.2. Assessment of reliability by Cronbach's Alpha value for all research constructs (concepts) (included all indicators)

Before conducting any other analyses, it is essential to assess reliability in any measurement scale. The reliability of items was assessed by computing the coefficient alpha that measures the internal consistency of the items. For a measure to be acceptable, the Cronbach's alpha should be above 0.7 while the item-to-total correlations exceed 0.50 (Hair et al., 2009).

Reliability dimension (5 variables: RL1, RL2, RL3, RL4, RL5). This dimension consists of 5 variables. Cronbach's alpha of reliability dimension is 0.776 higher than 0.7 , hence the measurement of reliability dimension of service quality is acceptable. Meanwhile, the corrected item-to-total correlation of RL1, RL5 doesn't exceed 0.5; hence RL5 will be eliminated in further analysis. Other items (i.e., RL2, RL3, and RL4) reached measurement standards and will be used in other analyses. Thus, the initial confidence scale consists of five variables, and only three variables (RL2, RL3, RL4) are retained for subsequent analyzes. With two disqualified variables (RL1 and RL5), the information of the RL1 variable may be unclear and is already expressed in another variable more clearly; Removed RL5 variable may explain that the respondent has different perspectives when evaluating this question. Nowadays, the status of spam messages is widespread (although controlled), which also causes troubles for many customers, and they will send requests to call/message center (or service providers) not to receive notifications. (e.g., MobiFone network subscribers refuse to receive notification messages, compose messages to the automatical center operator 9234- switchboard).

Assurance dimension (4 variables: A9, A10, A11, A12) Cronbach's alpha of assurance dimension is 0.830 higher than 0.7 , so the measurement of assurance dimension of service quality is acceptable. Meanwhile, the corrected item-to-total correlation of A12 doesn't exceed 0.5 ; hence A12 will be eliminated in further analysis. In terms of the meaning of the A12 variable, it is difficult for customers to assess the knowledge of the mobile service provider's employee. Regarding, the rest items of assurance dimension reached the standard measure of item-total correlation (exceed 0.5 ); so will be used in other analysis.

Responsiveness dimension (3 variables: RS6, RS7, RS8), Empathy dimension (4 variables E13, E14, E15, E16), Tangible dimension (5 variables: T17, T18, T19, T20, T21), Network quality dimension (5 variables: N22, N23, N24, N25, N26) the Cronbach's alpha are $0.85,0.896,0.881,0.912$ respectively higher than 0.7 , hence the measurement of these dimensions of service quality are acceptable. All items of the above-mentioned dimension reached the measurement standard of item-total correlation (exceed 0.5); thus they will be used in other analyses.

Reliability analysis of measurement scale of Customer value (2 variables: CV27, C28), Customer Satisfaction (3 variables SAT29, SAT30, SAT31), Behavioral intention (BI32, BI33, BI3) the Cronbach's alpha are $0.85,0.896,0.881,0.912$ respectively higher than 0.7 , hence the measurement of these dimensions are acceptable. All items of the above-mentioned dimension 
reached the measurement standard of item-total correlation (exceed 0.5); thus they will be used in other analysis.

\subsection{Exploratory factor analysis (EFA)}

\subsubsection{EFA for Service quality}

Thus according to the analysis result of Cronbach's Alpha, all 23 variables were analyzed using the Principal Axis Factoring method with the Promax rotation. The variables with factor loading less than 0.5 would be eliminated and priority should be given to eliminating the variable. the "worst"; repeat the operation until the variable output table has a load factor of less than 0.5. However, no variables are excluded because they all load factors that meet the requirements. After the EFA, the measure of service quality consists of 23 variables which were initially grouped into 5 factors instead of six as originally planned. The four factors (reliability, empathy, tangible, network quality) are kept unchanged, with three variables (A9, A10, A11) of the capacity factor and three variables (RS1, RS2, RS3). The response (mentioned) factors are previously grouped into a new factor and renamed to Personnel.

The KMO value is 0.862 ( $>0.5)$, Bartlett's test also indicates that the values are significant (Sig. $<0.05)$ is acceptable $(>0.5)$. Besides, the total variance was $71.49 \%(>50 \%)$ which represented five factors that accounted for $71.49 \%$ of 23 variables and thus acceptable. Based on the above-mentioned result, EFA is an appropriate method.

\subsubsection{FEA for customer satisfaction, customer value, behavior intention}

For these scales (constructs), factor analysis is done in turn for each concept among indicators. The results of the EFA analysis show that all variables have a load factor greater than 0.5 , the total covariance of the factors is greater than $50 \%$ showing the variability explained and the conditions in the analysis. EFA. The observational variables measuring the concepts remain unchanged from the expected. Specifically, customer satisfaction: 3 variables, customer value: 2 variables, behavior intention: 3 variables. Hence, all of these variables will be included in the path analysis.

\subsection{Statistical hypothesis testing (by Path Analysis)}

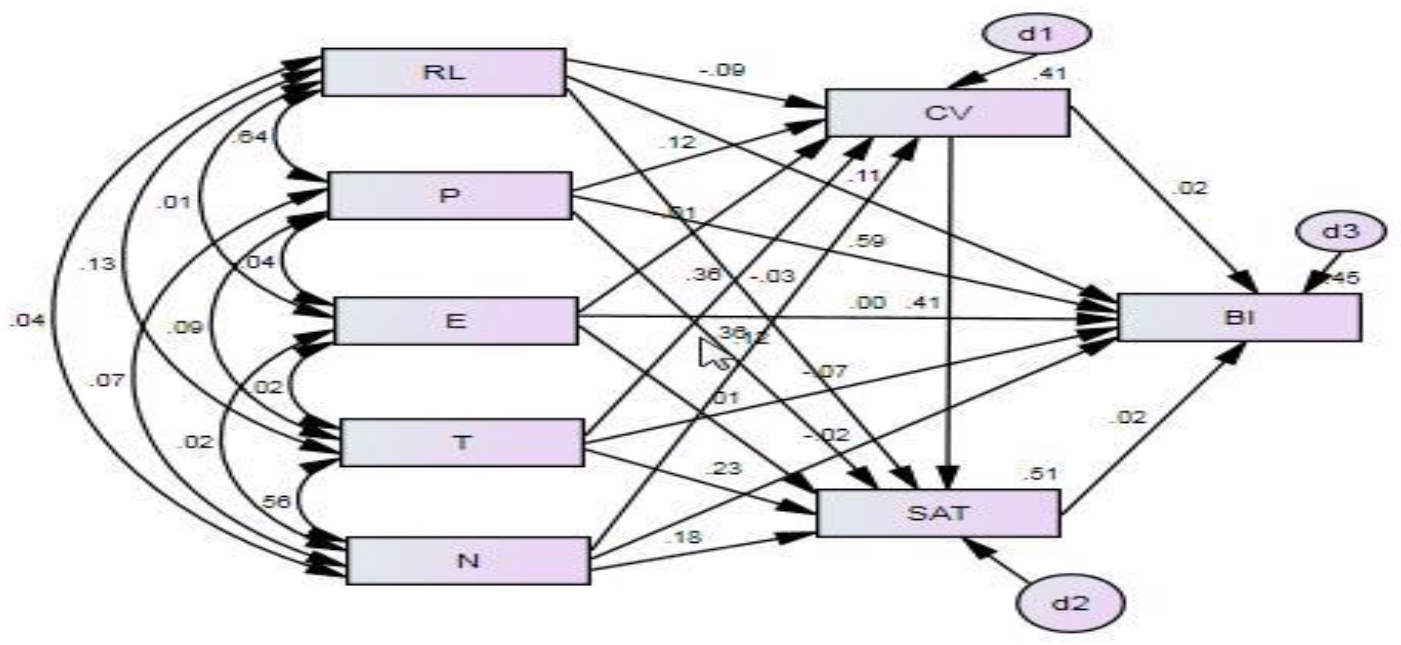

Figure 2. Standardized Path Analysis diagram 
As a result of the EFA, the composite variables representing each factor are calculated by adding the average value of the observed variables in terms of every construct (and total indicators). The Path Analysis model is shown in Figure 2. In the model, the service quality (SQ) in the HCM City market is measured through five aggregate variables. An abbreviation formed meaning: R: Reliability (R); P: Personnel; E: Empathy; T: Tangible - Tangible means; $\mathrm{N}$ : Network quality. In addition, there are some synthetic variables that represent other unidirectional concepts: CV: Customer value; SAT: Customer satisfaction; BI: Behavior intention.

\section{Table 2}

Summary direct, indirect and composite impacts (standardized)

\begin{tabular}{|c|c|c|c|c|c|c|c|c|}
\hline & & $\mathrm{RL}$ & $\mathrm{T}$ & $\mathrm{N}$ & $\mathrm{E}$ & $\mathrm{P}$ & $\mathrm{CV}$ & SAT \\
\hline \multirow[t]{3}{*}{$\mathrm{CV}$} & Direct & -0.089 & $0.359 * * *$ & $0.357 * * *$ & -0.007 & 0.117 & 0.000 & 0.000 \\
\hline & Indirect & 0.000 & 0.000 & 0.000 & 0.000 & 0.000 & 0.000 & 0.000 \\
\hline & Total & -0.089 & 0.359 & 0.357 & -0.007 & 0.117 & 0.000 & 0.000 \\
\hline \multicolumn{9}{|c|}{ SAT } \\
\hline & Direct & -0.032 & $0.225 * * *$ & $0.181 * * *$ & 0.015 & $0.122 *$ & $0.407 * * *$ & 0.000 \\
\hline & Indirect & -0.036 & 0.146 & 0.145 & -0.003 & 0.048 & 0.000 & 0.000 \\
\hline & Total & -0.069 & 0.372 & 0.327 & 0.012 & 0.170 & 0.407 & 0.000 \\
\hline \multicolumn{9}{|l|}{ BI } \\
\hline & Direct & 0.106 & -0.065 & -0.021 & -0.003 & $0.593 * * *$ & 0.024 & 0.022 \\
\hline & Indirect & -0.004 & 0.017 & 0.016 & 0.000 & 0.007 & 0.009 & 0.000 \\
\hline & Total & 0.102 & -0.048 & -0.005 & -0.003 & 0.600 & 0.033 & 0.022 \\
\hline
\end{tabular}

Note: $* * *, * * *$ The direct effects are statistically significant at $10 \%, 5 \%$, and $1 \%$

Source: The researcher's data analysis

As can be seen from the Table 2, it illustrates that the two components (indicators) of service quality constructs are (1) tangible and (2) network quality which has a direct, positive impact on service value at $1 \%$ level (standardized coefficients are 0.359 and 0.357 respectively). These two components (indicators) also act directly (indirectly) and indirectly (on the positive side) to customer satisfaction ( $\mathrm{T}$ and $\mathrm{N}$ indirectly influence the SAT through the $\mathrm{CV}$ ). In addition, customer satisfaction is directly influenced by service value at a $1 \%$ level (with a statistically significant value of 0.407 ).

As shown, Table 2 also demonstrates the direct and statistically significant (at $1 \%$ significance) impact of the human factor component (indicator) on behavior intention (with standardized coefficients value is 0.593 ). The human factor also indirectly influences behavior intention through the customer value (indirect standardized coefficients value is 0.007). On the sample scale, among the components (indicators) of service quality construct, the only human component that explains and plays the most important role in influencing behavior intention 
(direct relationships between other parts with BI construct is not statistically significant. The synthetic effect is 0.6 , the highest in absolute terms).

According to the results of direct, indirect, and combined effects (in Table 2), the direct effects between concepts (constructs) as well as the P-value of the regression coefficients (standardized and unstandardized) are shown in Table 3. The overall level of explanation for the model is $84 \%$.

The empirical results of this research in Viet Nam provide evidence that supports or does not support the hypotheses $\mathrm{H} 1, \mathrm{H} 2, \mathrm{H} 3, \mathrm{H} 4, \mathrm{H} 5$, and $\mathrm{H} 6$ differing significantly from that of Wang et al. (2004) made in China's mobile telecommunications market. Wang et al. (2004) concluded that the quality of the network quality, sympathy and tangible means are the three main drivers of customer value in the Chinese mobile telecommunication market, and this study also finds similarities. In contrast with Wang et al. (2004), this study found no evidence to support the influence of Empathy on customer value. The reason for this disagreement might be that the majority of Vietnamese subscribers are pre-paid, mostly "trendy" (23-34 year olds), who are apt to switch when facing problems with service providers. This also explains why Reliability and Personnel are not the key drivers of customer value on Vietnam's mobile telecommunication market. This also explains why the trustworthiness and human factor reflected in service quality is not a major factor in customer value in Vietnam's mobile telecommunications market (although the human factor has a direct impact on behavior intention).

\section{Table 3}

Unstandardized, Standardized statistical items (correlation between variables estimated), pvalue và $\mathrm{R}$ square

\begin{tabular}{|c|c|c|c|c|c|c|c|}
\hline & & & $\begin{array}{l}\text { Estimates } \\
\text { Unstandardize } \\
\text { d }\end{array}$ & $\begin{array}{l}\text { Standardize } \\
\text { d }\end{array}$ & S.E. & C.R. & P-value \\
\hline $\mathrm{CV}$ & $<--$ & $\mathrm{P}$ & 0.126 & 0.117 & 0.078 & 1.625 & 0.104 \\
\hline $\mathrm{CV}$ & $<---$ & RL & -0.081 & -0.089 & 0.066 & -1.237 & 0.216 \\
\hline $\mathrm{CV}$ & $<---$ & $\mathrm{N}$ & $0.339 * * *$ & 0.357 & 0.064 & 5.343 & 0.000 \\
\hline $\mathrm{CV}$ & $<---$ & $\mathrm{T}$ & $0.357 * * *$ & 0.359 & 0.067 & 5.344 & 0.000 \\
\hline $\mathrm{CV}$ & $<---$ & $\mathrm{E}$ & -0.008 & -0.007 & 0.061 & -0.132 & 0.895 \\
\hline SAT & $<---$ & $\mathrm{CV}$ & $0.455 * * *$ & 0.407 & 0.074 & 6.186 & 0.000 \\
\hline SAT & $<---$ & $\mathrm{N}$ & $0.192 * * *$ & 0.181 & 0.07 & 2.766 & 0.006 \\
\hline SAT & $<---$ & $\mathrm{P}$ & $0.147 *$ & 0.122 & 0.08 & 1.841 & 0.066 \\
\hline SAT & $<---$ & $\mathrm{T}$ & $0.251 * * *$ & 0.225 & 0.073 & 3.422 & 0.000 \\
\hline SAT & $<---$ & $\mathrm{E}$ & 0.018 & 0.015 & 0.063 & 0.29 & 0.772 \\
\hline SAT & $<---$ & RL & -0.033 & -0.032 & 0.067 & -0.488 & 0.625 \\
\hline BI & $<---$ & $\mathrm{P}$ & $0.699 * * *$ & 0.593 & 0.083 & 8.371 & 0.000 \\
\hline
\end{tabular}




\begin{tabular}{|c|c|c|c|c|c|c|c|}
\hline & & & $\begin{array}{l}\text { Estimates } \\
\text { Unstandardize } \\
\text { d }\end{array}$ & $\begin{array}{l}\text { Standardize } \\
\text { d }\end{array}$ & S.E. & C.R. & P-value \\
\hline BI & $<--$ & $\mathrm{E}$ & -0.003 & -0.003 & 0.065 & -0.049 & 0.961 \\
\hline BI & $<--$ & $\mathrm{N}$ & -0.022 & -0.021 & 0.073 & -0.298 & 0.765 \\
\hline BI & $<--$ & $\mathrm{T}$ & -0.071 & -0.065 & 0.078 & -0.904 & 0.366 \\
\hline BI & $<---$ & RL & 0.105 & 0.106 & 0.07 & 1.507 & 0.132 \\
\hline$\overline{B I}$ & $<--$ & $\mathrm{CV}$ & 0.026 & 0.024 & 0.083 & 0.315 & 0.753 \\
\hline BI & $<--$ & SAT & 0.022 & 0.022 & 0.074 & 0.291 & 0.771 \\
\hline \multicolumn{8}{|l|}{$\mathbf{R}^{2}$} \\
\hline $\mathrm{CV}$ & & & 0.410 & & & & \\
\hline SAT & & & 0.507 & & & & \\
\hline BI & & & 0.445 & & & & \\
\hline Total & & & 0.839 & & & & \\
\hline
\end{tabular}

Source: Data analysis result of the research

Wang et al. (2004) investigated the effect of quality-related factors on customer satisfaction using SEM in China's telecommunication industry. Their results indicated that service quality had positive and significant effects on customer satisfaction. Furthermore, they suggested that Reliability, Assurance, Tangible and Network quality were the key drivers of customer satisfaction. Woo and Fock (1999), on their research investigated the determinants of customer satisfaction in Hong Kong mobile phone service, identified transmission quality and network coverage as the key driver in the mobile phone market. Cronin et al. (2000) found support for the indirect effect of service quality on customer satisfaction through customer value. Moreover, the positive and significant influence of service quality on customer satisfaction also found support from Cronin et al. (2000), Turel and Serenko (2006).

\section{Conclusion and management findings}

The research of correlation and causal effects revolve around four concepts: components of service quality, customer value, customer satisfaction, and behavior intention. This study confirms the effect/impact of service quality on customer satisfaction. Value of service has an intermediary role in the causal relationship between service quality and customer satisfaction. There is no statistical evidence of the direct impact of customer value and customer satisfaction on behavior intention, the human factor in service quality has a direct impact on customer satisfaction, as well as behavior intention.

Detecting the relationship between concepts (constructs) based on indicators in this important marketing field is significant in quantifying and confirming the manager's ability to plan strategies for achieving expecting business success, and key factor operating excellence. Research results represent that in the service quality, the network quality (expressed by voice quality) and then the tangible component (expressed through the infrastructure equipment, Base 
Transceiver Station-BTS) should be of interest to the providers. Service providers investing in developing modern infrastructure to increase signal transmission and improve network quality are indispensable. In addition, the typical human factor is an attitude of service that implies a psychological impact on customer perception of service. However, it should not be neglected to maintain or increase the reliability factor as well as other factors of service quality, as it may directly affect customer satisfaction and value. Existing research sample (based on nonprobability sampling method), this study has not found statistical evidence.

It can be denied that limitations of scientific research topics due to limited capacity and time during implementation, the topic is not avoided from the following limitations:

First of all, because of using a convenient method, the number of small samples cannot be completed.

All are highly representative, in which case the method should be chosen sample that is more representative: stratified sampling, grouping. Second, in the process transliteration from questions asked corresponding to the variables in the original English question head to the Vietnamese questionnaire despite trying but inevitably mistakes, though try to explain in detail the questions that the respondents can understand and avoid understanding wrong for the respondents. Third, research is done in a specific industry (mobile information) needs to be expanded. Experimental research for other sectors should be carried out to test the reliability of the scale (especially the scale of customer value) and the appropriateness of the model and consideration in the aggregate for the whole service industry. Fourth, the research is only done in Ho Chi Minh City. This limits the level the generalization of the results at some level. In the future, it should be done with wider scope whereby the level of generalization will also increase.

\section{ACKNOWLEDGEMENTS}

The authors sincerely thanks for the support and encouragement of some scientists: Master. Hang Le Cam Phuong, Dr. Vu The Dung, Ass. Prof. Dr Nguyen Hau, and lecturers at the Faculty of Industrial Management (HCMC University of Technology). This study was hardly completed without the support of the interviewees who answered questionnaires and we would like to share this paper with friends and relatives.

\section{References}

Adil, M., Ghaswyneh, O. F. M. A., \& Albkour, A. M. (2013). Servqual and servperf: A review of measures in services marketing research. Global Journal of Management and Business Research Marketing, 13(6), 65-69.

Anderson, J. C., Jain, D. C., \& Chintagunta, P. K. (1992). Customer value assessment in business markets: A state-of-practice stud. Journal of Business to Business Marketing, 1(1), 3-29. doi:10.1300/J033v01n01_02

Cronin, J. J., \& Taylor, S. A. (1992). Measuring service quality: A re-examination and extension. Journal of Marketing, 56(3), 55-68. doi:10.2307/1252296 
Cronin, J. J., Brady, M. K., \& Hult, G. T. (2000). Assessing the effects of quality, value, and customer satisfaction on consumer behavioral intentions in service environments. Journal of Retailing, 76(2), 193-218. doi:10.1016/S0022-4359(00)00028-2

Dao, K. X. (2017). Mô hình chất lượng dịch vụ trong bán lẻ: Giải pháp dành cho doanh nghiệp bán lẻ và doanh nghiệp kinh doanh dịch vụ. [Service quality model in retail: Solutions for retail and service businesses]. Hanoi, Vietnam: NXB Công Thương.

Edvardsson, B., Thomasson, B., \& OvretVeit, J. (1994). Quality of service: Making it work. New York, NY: McGraw-Hill.

Engel, J. F., Blackwell, R. D., \& Miniard, P. W. (1995). Consumer Behavior (6th ed.). New York, NY: Dryden Press.

Hoang Trong, \& Chu, N. N. M. (2005). Phân tích dĩu liệu nghiên cứu với SPSS. [Analyzing research data with SPSS] . Hanoi, Vietnam: NXB Thống kê.

Kotler, P. (2001). A framework for marketing management. Upper Saddle River, NJ: PrenticeHall.

Kotler, P., Amstrong, G., Saunders, J., \& Wong, V. (1997). Principles of marketing. London, UK: The European Edition, Prentice Hall.

Kotler, P., \& Amstrong, G. (2003). Nhũng nguyên lý tiếp thị (tập 2). [Principles of marketing (Vol. 2)] . Hanoi, Vietnam: NXB Thống kê.

Kotler, P., \& Keller, K. L. (2006). Marketing management (14th ed.). New York, NY: Pearson Prentice Hall.

McDougall, G. H. G., \& Levesque, T. (2000). Customer satisfaction with services: Putting perceived value into the equation. Journal of Services Marketing, 14(5), 392-410. doi:10.1108/08876040010340937

Nguyen, T. D. (2013). Phurong pháp nghiên cứu khoa học trong kinh doanh. Tái bản lần 2. [Scientific research method in business (2rd ed.).] . Hanoi, Vietnam: NXB Tài chính.

Oliver, R. L., \& Bearden, W. O. (1985). Disconfirmation processes and consumer evaluations in product usage. Journal of Business Research, 13(3), 235-246. doi:10.1016/01482963(85)90029-3

Parasuraman, A., Zeithaml, V. A., \& Berry, L. L. (1985). A conceptual model of service qualityand its implications for future research. Journal of Marketing, 49(4), 41-50.

Parasuraman, A., Zeithaml, V. A., \& Berry, L. L. (1988). Servqual: A multipleitem scale for measuring consumer perceptions of service quality. Journal of Retailing, 64(1), 12-40.

Parasuraman, A., Zeithaml, V. A., \& Berry, L. L. (1998). Perceived service quality as a customer-based performance measure: An empirical examination of organizational barriers using an extended service quality model. Human Resource Management 30(3), 335-364. doi:10.1002/hrm.3930300304 
Phan, A. C. (2015). Chất lương dịch vu tại các doanh nghiệp Việt Nam. [Service quality at businesses in Vietnam. ]. Hanoi, Vietnam: NXB Đại học Quốc Gia Hà Nội.

Turel, O., \& Serenko, A. (2006). Satisfaction with mobile services in Canada: An empirical investigation. Elsevier Telecommunications Policy, 30(5), 314-331. doi:10.1016/j.telpol.2005.10.003

Vu, D. T. (2002). Tiếp thị giũa các tổ chức. [Marketing Organization] . Ho Chi Minh City, Vietnam: NXB Đại học Quốc Gia TP. HCM.

Wang, Y., Lo, H. P., \& Yang, Y. (2004). An integrated framework for service quality, customer value, satisfaction: Evidence from China's telecommunication industry. Information Systems Frontiers, 6(4), 325-340. doi:10.1023/B:ISFI.0000046375.72726.67

Woo, K.-S., \& Fock, H. K. Y. (1999). Customer satisfaction in the Hong Kong mobile phone industry. The Service Industry Journal, 19(3), 162-174. doi:10.1080/02642069900000035

Woodruff, R. B. (1997). Customer value: The next source for competitive advantage. Journal of the Academy of Marketing Science, 25(2), 139-153. doi:10.1007/BF02894350.

Zeithaml, V. A. (1988). Consumer perceptions of price, quality, and value: A means-end model and synthesis of evidence. Journal of Marketing, 52(3), 2-22. doi: $10.1177 / 002224298805200302$

Zeithaml, V., Berry, L., \& Parasuraman, A. (1996). The behavioral consequences of service. Journal of Marketing, 60(2), 31-46. doi:10.2307/1251929

Zeithaml, V. A., \& Bitner, M. J. (2000). Services marketing: Integrating customer focus across the firm. Boston, MA: Irwin McGraw- Hill. 